\title{
Laser Texturization to Decrease Reflectance of Polycrystalline Silicon Wafers
}

\author{
Monireh Ganjali ${ }^{*}$, Mansoureh Ganjali*, Parvaneh Sangpour ${ }^{*}$, Ali Khanlarkhani ${ }^{*}$, Mohammad Ali Meshkot ${ }^{*}$ \\ *Nanotechnology and Advanced Materials Department, Materials and Energy Research Center \\ (MERC), P.O.Box 14177-4777 Tehran, Iran \\ Email:monireh_110@yahoo.com,monireh.gan@merc.ac.ir
}

\begin{abstract}
In the present work, laser ablation as a method for texturization of a polycrystalline silicon surface is studied. This involves creating a roughened surface in order to decrease reflection from the surface of a wafer. A special etching procedure was applied to remove the laser-damaged layer. The textured surface was observed using a field emission scanning electron microscope and an atomic force microscope. The surface reflectance was also measured and the results show that chemical etching needs to be applied after laser processing in order to achieve reduced reflection from a lowdefect surface.
\end{abstract}

DOI:10.2961/jlmn.2012.01.0012

Keyword: laser ablation, texture, polycrystalline silicon, reflectance, etching

\section{Introduction}

The energy crisis is one of the greatest challenges facing mankind. Nowadays, most energy sources are supplied by fossil fuels, but it's necessary to develop alternative sources in order to have cheaper and cleaner energy in the feature.

There are many alternative sources to fossil fuels. Solar energy is one of them. But, the biggest challenge in using solar energy is its cost relative to other sources. To be free of fossil fuels dependence requires a technological development to reduce the cost of alternatives. Inverters, lower cost distribution, storage and other infrastructure are necessary. Furthermore, the cost of manufacturing efficient solar cells needs to be reduced.

At present, photovoltaic devices based on both mono- and poly-crystalline silicon are most used around the world. The drawback of these devices are low efficiency for mono and high cost for poly-crystalline forms[1]. As the refractive index of silicon is very high, reflection at the surface of solar cells needs to be minimized in order to absorb more energy from sunlight. Minimizing the reflection is achieved by treating the silicon wafer surface. All solar cells manufactured today have an antireflective coating consisting of a transparent film of low refractive index. But this is expensive and time-consuming.

Surface texturization is a better method of achieving reduced reflectance because of higher processing speed and lower cost. There are several types of texturization techniques for polycrystalline silicon including acid texturization [2-7], reactive ion etching [8], and mechanical texturization $[9,10]$.

Chemical and electromechanical techniques are more effective for texturing of monocrystalline silicon [11]. However these methods are inefficient for polycrystalline silicon due to multiple crystallographic

grain orientations and highly selective etching along specific directions [11-13].

Many other techniques have been used to texturize polycrystalline silicon solar cells. One of these techniques is the use of isotropic etching by a photolithography method $[14,15]$. The result is a honeycomb pattern of hemispherical pits that reduce reflection effectively. Another technique is using a blade to produce v-grooves on the silicon wafer [9, 16-18]. However this is difficult in practice due to the high breakability and brittleness of polycrystalline silicon wafers. Furthermore, mechanical scribing of hard silicon materials often causes considerable damage around the scribed region which generally requires larger separation between scribe lines. Therefore a more efficient technique needs to be developed.

Today, lasers are successfully used for the surface treatment of solar cells in order to increase absorption of the incident solar radiation by creating different patterns of grooving, scribing, cutting, and making holes in photovoltaic cells [1, 19-22].

The object of the present work is to develop laser methods for surface texturization using a Nd:YAG laser to scribe polycrystalline silicon wafers used for solar cells in order to reduce their reflectance.

\section{Experimental}

\subsection{Materials}

Experiments were carried out on p-type borondoped polycrystalline silicon wafers of thickness $330 \pm 10$ $\mu \mathrm{m}$, area $1 \mathrm{~cm} \mathrm{x} 1 \mathrm{~cm}$ and resistivity $1 \Omega \mathrm{cm}$.

\subsection{Removal of Saw Damage by Etchant}

Surface damage induced by wire-cutting was removed from cut samples by etching in a $20 \mathrm{wt} \% \mathrm{KOH}$ solution at $80^{\circ} \mathrm{C}$ for 10 minutes. Typically, about $11 \mu \mathrm{m}$ of distorted material was etched away leaving a clean damage-free surface. The surface was washed with distilled water and oven dried for 1 hour at $110^{\circ} \mathrm{C}$. The polycrystalline silicon surface before and after etching are shown in fig. 1 (a) and (b) respectively. 


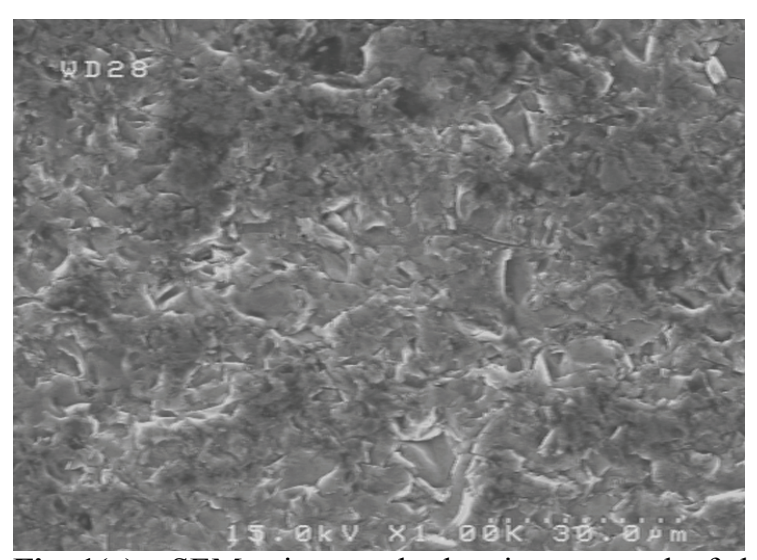

Fig. 1(a) SEM micrograph showing removal of defects from the as-cut silicon surface before etching.

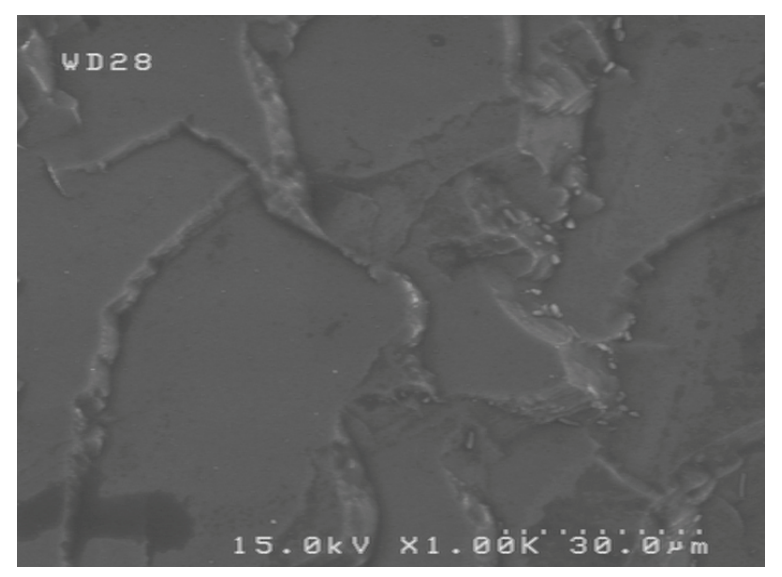

Fig. 1(b) SEM micrograph showing removal of defects from the as-cut silicon surface after etching in $20 \mathrm{wt} \%$ $\mathrm{KOH}$ solution for 10 minutes.

\subsection{Laser Treatment and Observation Tools}

In order to reduce surface reflection, texturization was carried out on the top surface of silicon wafers using a pulsed Nd:YAG laser having the parameters given in Table 1. The beam was focused and fixed normal to the sample surface and the sample was set on a stage with programmable $\mathrm{X}-\mathrm{Y}$ motion. The sample was thus moved through the beam.

Table 1 - Laser parameters

\begin{tabular}{|l|l|}
\hline Laser & $\begin{array}{l}\text { Q-Switched, Nd:YAG, } \\
\text { TEM }_{00}\end{array}$ \\
\hline Wavelength & $1064 \mathrm{~nm}$ \\
\hline Average power & $15 \mathrm{~W}$ \\
\hline Repetition frequency & $2-10 \mathrm{kHz}$ \\
\hline Laser scan beam speed & $20-700 \mathrm{~mm} / \mathrm{s}$ \\
\hline Beam quality profile & $\mathrm{M}^{2}=1.2$ \\
\hline
\end{tabular}

The topography of the laser textured surfaces was investigated using a Hitachi S4160 Scanning Electron Microscope (SEM) and an Atomic Force Microscope (AFM). Furthermore, the surface reflectance was measured using a Perkine-Elmer Lambda Spectrophotometer.

\section{Result and discussion}

Uniform parallel grooves having a depth of $85 \pm 5 \mu \mathrm{m}$ and a separation of $100 \pm 10 \mu \mathrm{m}$ were cut by the laser beam as shown in fig. 2 and 3. Fig. 4 and 5 show SEM micrographs of a single groove cut by the laser beam traversing at $50 \mathrm{~mm} / \mathrm{s}$ on the silicon surface followed by etching with $20 \% \mathrm{KOH}$ at $80{ }^{\circ} \mathrm{C}$. Flat planes show the underlying crystalline structure. During laser grooving, some silicon boils off due to the high temperatures involved and some melts and solidifies around the groove and within the heat-affected zone (HAZ). Hence the unetched textured silicon surface contains some residual material and numerous crystallographic defects. It is important to remove this residual and defective material in order to improve the electrical efficiency [23].

In order to remove these residual materials from the surface and grooves, the laser treated silicon surface was etched using a $20 \% \mathrm{KOH}$ solution (fig. 4 and fig.5). In this case, the etching time required to remove the residual ablation by-product results in an increased flattening of the surface. Note that for deep grooves the etching procedure needs to be longer in order to remove the sediments at the bottom of grooves. This is because removal of material is slower from the base of deep grooves due to slower molecular transport of the etchant.

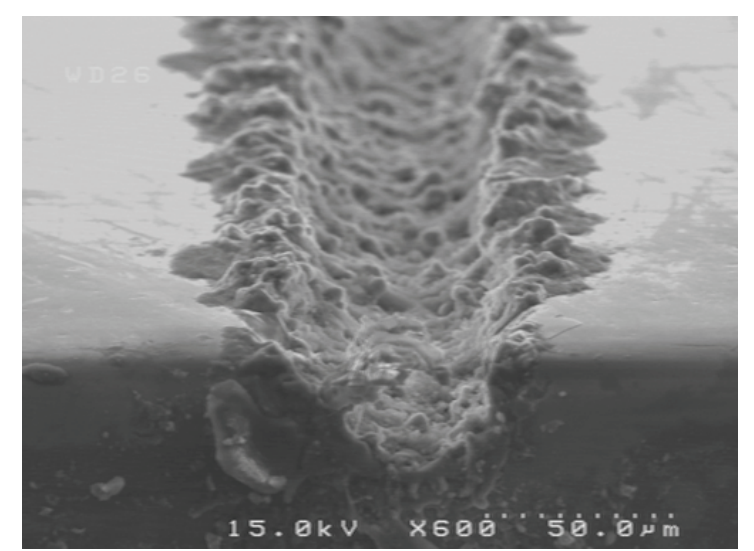

Fig. 2 SEM micrograph showing a single groove cut by the laser beam traversing at $50 \mathrm{~mm} / \mathrm{s}$ on the silicon surface. 


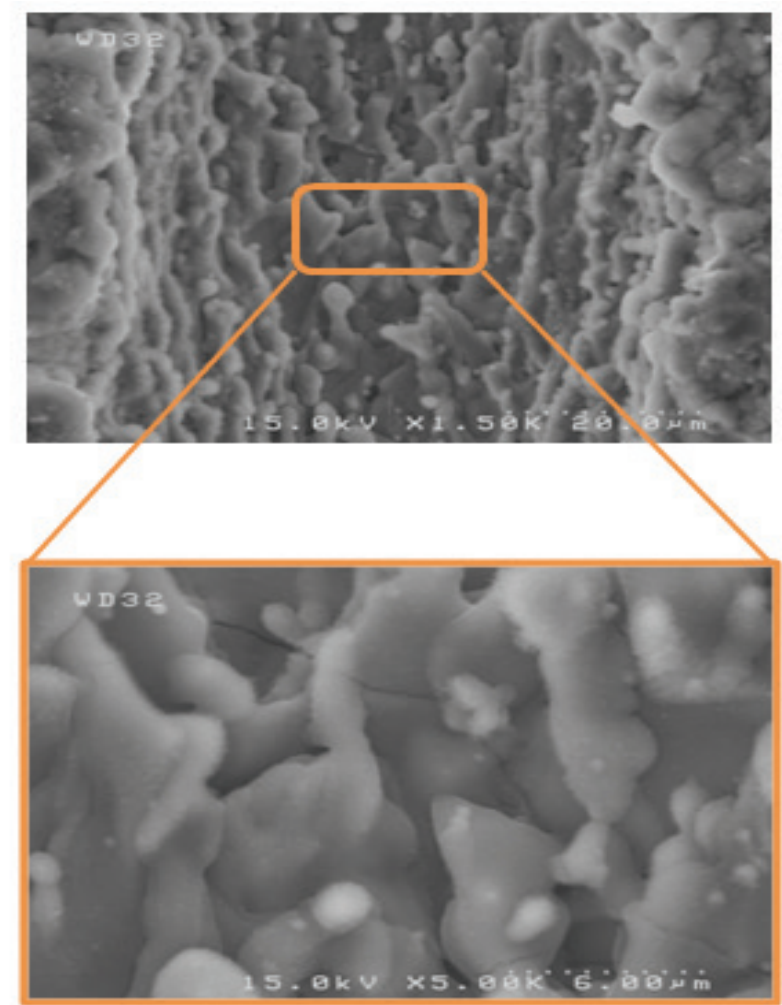

Fig. 3 SEM micrographs of laser texturization showing groove walls as produced with a laser beam traversing at $50 \mathrm{~mm} / \mathrm{s}$ without further treatment.
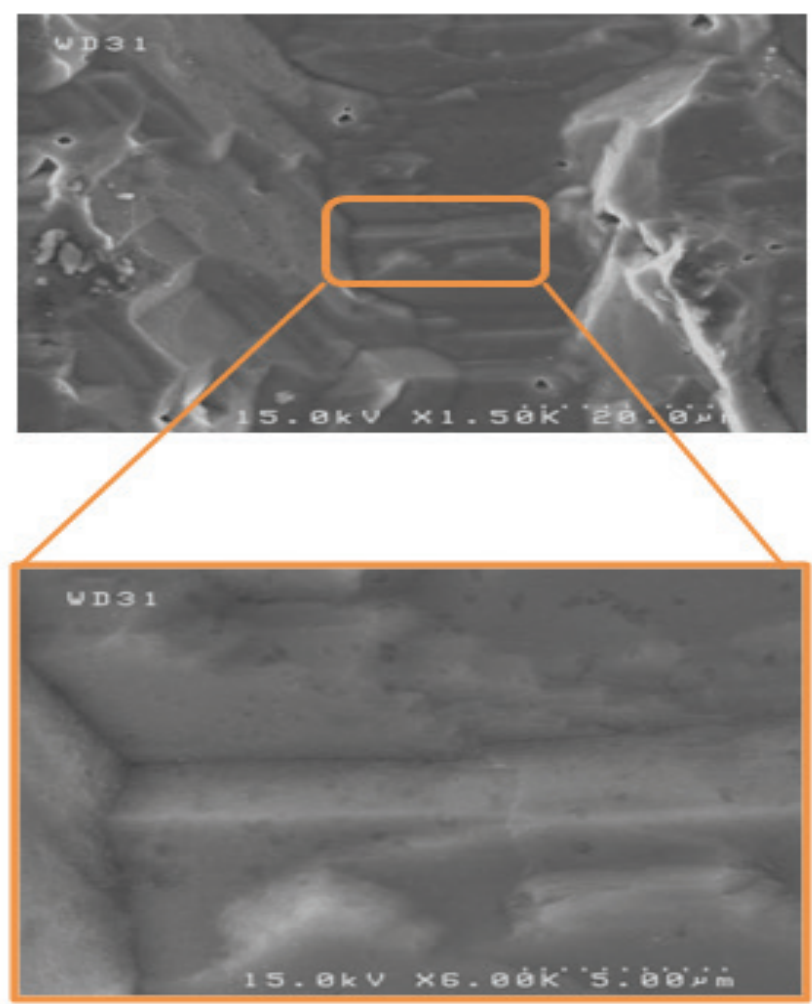

Fig. 4 SEM micrographs of laser texturization showing groove walls as produced with a laser beam traversing at $50 \mathrm{~mm} / \mathrm{s}$ followed by 10 minutes etching with $20 \% \mathrm{KOH}$ at $80{ }^{\circ} \mathrm{C}$. Flat planes show the underlying crystalline structure.

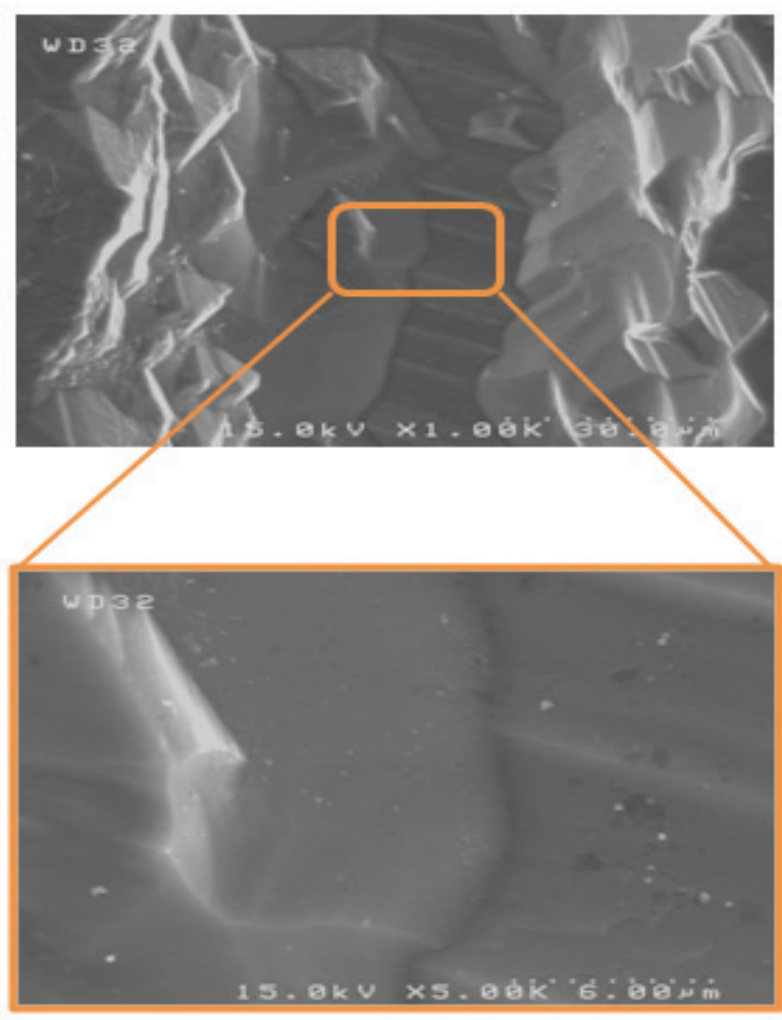

Fig.5 SEM micrographs of laser texturization showing groove walls as produced with a laser beam scanning speed of $50 \mathrm{~mm} / \mathrm{s}$ followed by 20 minutes etching with $20 \% \mathrm{KOH}$ at $80{ }^{\circ} \mathrm{C}$. Flat planes show the underlying crystalline structure.

AFM having the operating parameters of Table 2 was used to confirm the removal of laser-induced defects from groove vertices by $\mathrm{KOH}$ etchant (fig.6). AFM Images taken inside of the grooves before and after etching clearly show reduced molten and recrystalized silicon material at the bottom of grooves.

AFM images showed a remarkable microscopic aggregation and roughness within grooves, a clean edge to the grooves and a smooth uniform surface between grooves. The non-uniform lateral edge of fig. 6 (a) is attributed to the AFM needle imaging diameter being larger than the observed area of lanes between grooves.

Fig. 5 images also confirm that etching after laser cutting results in better groove uniformity. On the other hand, it should be mentioned that repeated or prolonged etching, under the same conditions of temperature and concentration, can result in texture smoothing, which is undesirable because it increases surface reflection. So a balance needs to be met between laser texturizing of doped silicon solar-cell wafers to reduce reflectance and the smoothing which results from surface defect removal by etchant. 
Table 2 - Atomic Force Microscope Settings

Dualscope/ Raster-
scope C26, DME,
Denmark
Technical specifica-
tions for DS 95-50-E
scanner:
scanner:

- X, Y scan size: $50 \times$ $50 \mu \mathrm{m}$

- $\mathrm{X}, \mathrm{Y}$ resolution: $<$ $0.1 \mathrm{~nm}$

- $\mathrm{Z}$ range: $2.7 \mu \mathrm{m}$

- $\mathrm{Z}$ resolution: $<0.1$ $\mathrm{nm}$

Probes specifications:

AC Probe: DS 95-200/50

- Probe Geometry: Length: $230 \mu \mathrm{m}$ Width: $40 \mu \mathrm{m}$ Thickness: $7 \mu \mathrm{m}$

- Tip: conical Height: 15-20 $\mu \mathrm{m}$ Angle: $<20$ degrees
- For use with: DualScope ${ }^{\mathrm{TM}}$ Cantilever: Rectangular Curvature radius: $<10 \mathrm{~nm}$

- Force constant: 25-60 N/m

- Cantilever coating: Aluminum

- Silicon tip: Mikromasch NSC16

- Resonance freq.: 150-190 $\mathrm{kHz}$ (1.mode)

- Q-factor: Typically 500

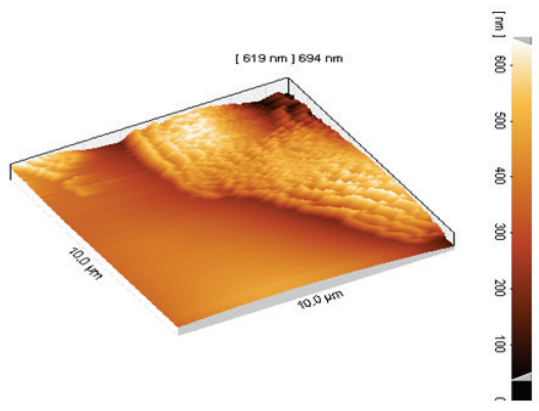

Fig. 6 (a) AFM images of laser-grooved silicon wafer surface with a beam traversing speed of $50 \mathrm{~mm} / \mathrm{s}$ and no etching,

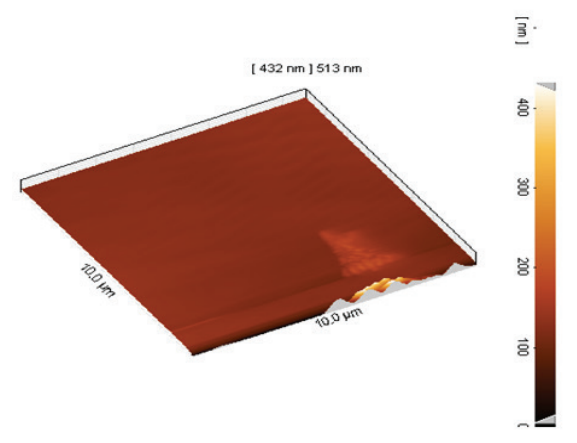

Fig. 6 (b) As fig. 6 (a) but after 10 minutes etching with $20 \% \mathrm{KOH}$ at $80{ }^{\circ} \mathrm{C}$.

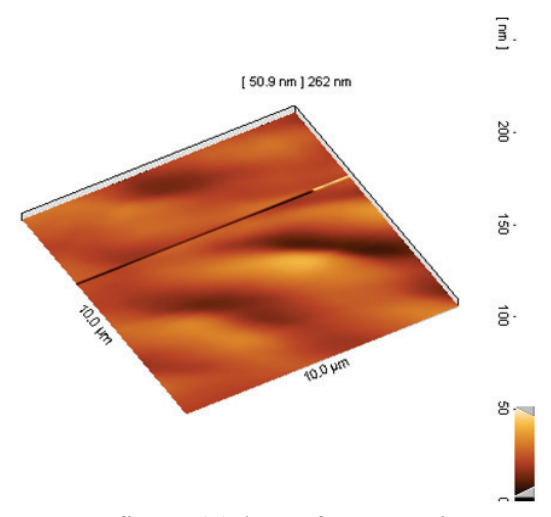

Fig.6 (c) As fig. 6 (a) but after 20 minutes etching with $20 \% \mathrm{KOH}$ at $80^{\circ} \mathrm{C}$.

Channel Roughness was measured over an area of $0.5 \mathrm{~cm}^{2}$ using a total integrated scattering method (TIS) [24]. In this method the specular and diffusely scattered laser light of wavelength $\lambda$ from a surface is measured which relates to the root-mean-squared (RMS) of surface roughness $\sigma$ according to the general relationship (1) [25, $26]$.

$$
T I S=\left(\frac{4 \pi \sigma}{\lambda}\right)^{2}
$$

Relation (2) shows the approximate relation between the average roughness parameter $(\mathrm{Ra})$ and RMS roughness $(\sigma)$.

$$
\mathrm{Ra} \approx 0.8 \sigma
$$

$\sigma$ is the roughness measured from RMS of peaks and valleys, whereas $\mathrm{Ra}$ is based on the arithmetic mean which represents the average of all peaks and valleys within the measurement area.

Fig. 7 and 8 respectively show the surface roughness $\sigma$ and $\mathrm{Ra}$ of laser treated specimens with post etching as a function of layer thickness removed by etching. Increasing the etching time leads to an increase of removed surface layers and there is a non-linear decrease in the surface roughness.

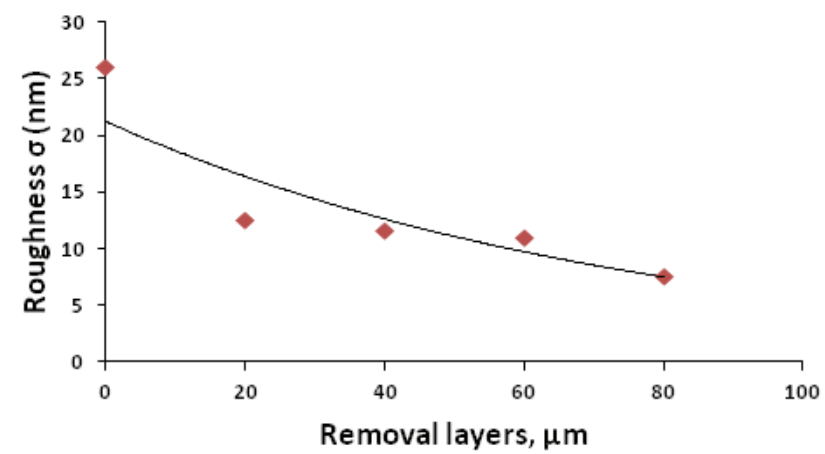

Fig. 7 Surface roughness $\sigma$ of laser treated specimens with post etching as a function of layer thickness removed by etching. 


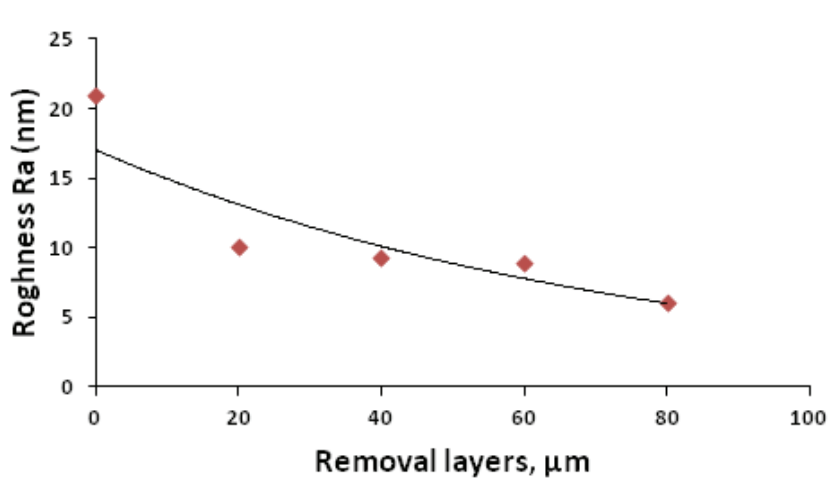

Fig. 8 Roughness parameter $(\mathrm{Ra})$ of laser treated specimens with post etching as a function of layer thickness removed by etching.

After cutting grooves with optimized depth and width, and after applying the defect removal treatment, the reflectance of textured wafers was measured by a PerkinElmer Lambda spectrophotometer. Additionally, the reduction of reflectance was characterized by effective reflectance defined as [27]:

$$
R_{e f f}=\frac{\int_{300}^{1100} R(\lambda) N(\lambda) d \lambda}{\int_{300}^{1100} N(\lambda) d \lambda}
$$

where $R(\lambda)$ is the total reflectance and $N(\lambda)$ is the solar flux under AM1.5 standard conditions.

Laser processing of the silicon wafer surface has a significant impact on its optical properties. Laser texturing allows for decreased reflectance compared to untreated wafers as shown in fig.9. The Reduction in reflection after texturing and etching procedure is shown in Table 4.

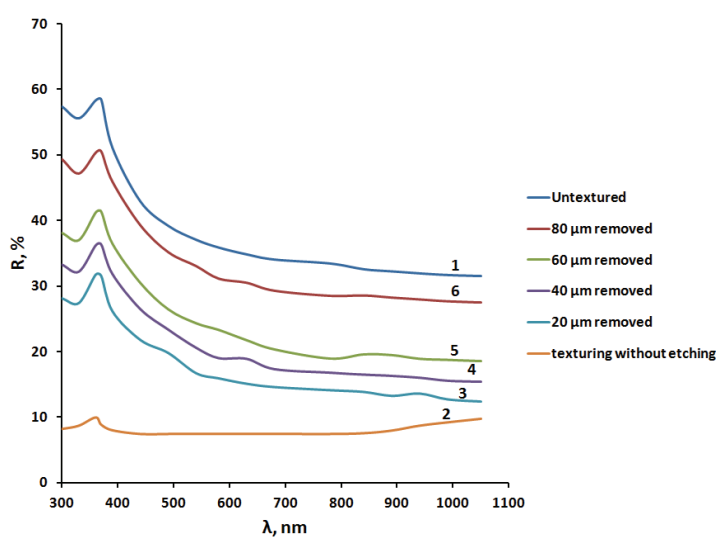

Fig. 9 Reflectance (R) from wafers with parallel grooves produced by laser texturing and after etching to remove varying thickness of the heat-affected layer. See Table 4.

Table 4 - Effective reflectance for modified wafers after progressive removal of laser induced damaged layer

\begin{tabular}{l|c|c}
\hline \multicolumn{1}{c|}{ Treatment } & $\begin{array}{c}\text { Label in } \\
\text { fig. 6 }\end{array}$ & $\begin{array}{c}\text { Effective } \\
\text { reflectance }\end{array}$ \\
\hline $\begin{array}{l}\text { Untextured and untreated silicon } \\
\text { wafer surface }\end{array}$ & 1 & 34.8 \\
\hline $\begin{array}{l}\text { Parallel groove Texturing, but } \\
\text { without etching }\end{array}$ & 2 & 10.0 \\
\hline $20 \mu \mathrm{m}$ removed by etching & 3 & 18.0 \\
\hline
\end{tabular}

\begin{tabular}{l|c|c}
\hline $40 \mu \mathrm{m}$ removed by etching & 4 & 21.16 \\
\hline $60 \mu \mathrm{m}$ removed by etching & 5 & 25.2 \\
\hline $80 \mu \mathrm{m}$ removed by etching & 6 & 30.3 \\
\hline
\end{tabular}

\section{Conclusion}

Compared to conventional methods, laser processing is a promising method for texturing polycrystalline silicon regardless of the crystallographic grain orientation.

Polycrystalline silicon surface texturing by Nd:YAG laser can increase solar radiation absorption due to internal reflection within laser-cut groove walls. After laser processing, a damaged surface layer is removed by etching in a $20 \%$ solution of $\mathrm{KOH}$ at $80^{\circ} \mathrm{C}$. Removal of this heat-damaged layer after laser processing reduces surface reflectance compared to the non-textured surface.

Continuing to remove layers after texturing to remove laser treatment sediments from the groove apex resulted in smoothing-out of the surface, and ultimately a rise in reflectance towards the untreated surface.

The advantage of laser structuring is that it enables the formation of sharp and precise features on the surface without the need of prior patterning of a mask. However, the silicon in laser-ablated regions is damaged, and typically needs a subsequent wet chemical damage etch.

\section{Acknowledgments}

This work has been supported by Materials and Energy Research Center (MERC) in frame of the Project No. 728810. Also, the authors would like to thank Dr. Zirak Head of Solid State Lasers at NSTRI Laser \& Optics Research School and Mina Baradaran from NSTRI Laser \& Optics Research School for roughness measurements.

\section{References}

[1] A. D. Compaan, I. Matulionis, and S. Nakade, "Laser scribing of polycrystalline thin films," $O p$ tics and Lasers in Engineering, vol. 34, pp. 15-45, 2000.

[2] V. Y. Yerokhov, R. Hezel, M. Lipinski, R. Ciach, H. Nagel, A. Mylyanych, and P. Panek, "Costeffective methods of texturing for silicon solar cells," Solar Energy Materials and Solar Cells, vol. 72, pp. 291-298, 2002.

[3] R. Einhaus, E. Vazsony, J. Szlufcik, J. Nijs, and R. Mertens, "Isotropic texturing of multicrystalline silicon wafers with acidic texturing solutions," 26th IEEE Photovoltaic Specialists Conference (PVSC), pp. 167-170, 1997.

[4] Y. Nishimoto, T. Ishihara, and K. Namba, "Investigation of Acidic Texturization for Multicrystalline Silicon Solar Cells," J. Electrochem. Soc, vol. 146, pp. 457-461, 1999.

[5] A. Hauser, I. Melnyk, P. Fath, S. Narayanan, S. Roberts, and T. M. Bruton, "A simplified process for isotropic texturing of mc-Si," Third World Conference on Photovoltaic Energy Conversion (WCPEC-3), 2003. 
P. Panek, M. Lipiski, and J. Dutkiewicz, "Texturization of multicrystalline silicon by wet chemical etching for silicon solar cells," Journal of Materials Science, vol. 40, pp. 1459-1463, 2005.

[7] J. Szlufcik, F. Duerinckx, J. Horzel, E. Van Kerschaver, H. Dekkers, S. De Wolf, P. Choulat, C. Allebe, and J. Nijs, "High-efficiency low-cost integral screen-printing multicrystalline silicon solar cells," Solar Energy Materials \& Solar Cells, vol. 74, pp. 155-163, 2002.

[8] G. Kumaravelu, M. M. Alkaisi, and A. Bittar, "Surface texturing for silcon solarcells using reactive ion etching technique," Photovoltaic Specialist Conference New Orleans Louisiana, pp. 258261, 2002.

[9] P. Fath, C. Marckmann, E. Bucher, and G. Willeke, "Multicrystalline silicon solar cells using a new high throughput mechanical texturization technology and a roller printing metallization technique," 13th European PV Solar Energy, pp. 29-32, 1995.

[10] C. Gerhards, C. Marckmann, R. Tolle, M. Spiegel, P. Fath, and G. Willeke, "Mechanically Vtextured low cost multicrystalline silicon solar cells with a novel printing metallization," 26th IEEE Photovoltaic Specialists, PVSC'97 Anaheim, CA, pp. 43-46, 1997.

[11] J. Nijs, S. Sivoththaman, J. Szlufcik, K. De Clercq, F. Duerinckx, E. Van Kerschaever, R. Einhaus, J. Poortmans, T. Vermeulen, and R. Mertens, "Overview of solar cell technologies and results on high efficiency multicrystalline silicon substrates," Solar Energy Materials and Solar Cells, vol. 48, pp. 199-217, 1997.

[12] U. Gangopadhyay, S. K. Dhungel, P. K. Basu, S. K. Dutta, H. Saha, and J. Yi, "Comparative study of different approaches of multicrystalline silicon texturing for solar cell fabrication," Solar Energy Materials and Solar Cells, vol. 91, pp. 285-289, 2007.

[13] H. Seidel, L. Csepregi, A. Heuberger, and H. Baumgartel, "Anisotropic etching of crystalline silicon in alkaline solution. Orientation dependence and behavior of passivation layers," Journal of the Electrochemical Society, vol. 137, pp. 36123626, 1996.

[14] J. Stocks, A. J. Carr, and A. W. Blakers, "Texturing of polycrystalline silicon," Solar Energy Materials and Solar Cells, vol. 40, pp. 33-42, 1996.

[15] J. Zhao, A. Wang, P. Campbell, and M. A. Green, "A $19.8 \%$ efficient honeycomb multicrystalline silicon solar cell with improved light trapping," IEEE Transactions on Electron Devices, vol. 46 pp. 1978-1983, 1999.

[16] G. Willeke, H. Nussbaumer, H. Bender, and E. Bucherer, "A simple and effective light trapping technique for polycrystalline silicon solar cells," Solar Energy Materials and Solar Cells, vol. 26, pp. 345-356, 1992.

[17] H. Nakaya, M. Nishida, Y. Takeda, S. Moriuchi, T. Tonegawa, T. Machida, and T. Nunoi, "Polycrystalline silicon solar cells with V-grooved sur- face," Solar Energy Materials and Solar Cells, vol. 34, pp. 219-225, 1994.

[18] R. Hezel, "A novel approach to cost effective high efficiency solar cells," 13th European PV Solar Energy, pp. 115-118, 1995.

[19] L. A. Dobrzanski and A. Drygala, "Surface texturing of multicrystalline silicon solar cells," Achievements in Materials and Manufacturing Engineering, vol. 31, pp. 72-82, 2008.

[20] U. Besi-Vetrella, E. Salza, L. Pirozzi, S. Noel, A. Slaoui, and J. C. Muller, "Selective doping of silicon by rapid thermal and laser assisted processes," Materials Science in Semiconductor Processing, vol. 1, pp. 325-329, 1998.

[21] H. J. Booth, "Recent applications of pulsed lasers in advanced materials processing," Thin Solid Films, vol., pp. 450-457, 2004.

[22] D. Kray, S. Baumann, K. Mayer, A. Eyer, and G. P. Willeke, "Novel Techniques for low-damage microstructuring of silicon," 20th European Photovoltaic Solar Energy, Barcelona, pp. 156-159, 2005.

[23] Z. M. Jarzebski, Solar Energy: Photovoltaic conversion, PWN, Warsaw, 1990.

[24] H. E. Bennett, "Scattering characteristics of optical materials," Optical Engineering, vol. 17, pp. 480-488, 1978.

[25] J. A. Ogilvy, Theory of Wave Scattering from Random Rough Surfaces, Institute of Physics Publishing, Philadel-phia, 1992.

[26] J. M. Bennett, Intro-duction to Surface Roughness and Scattering, Op Soc of America, Washington, D.C., 1999.

[27] P. Menna, G. Di Francia, and V. La Ferrara, "Porous silicon in solar cells, A review and description of its application as an AR coating," Solar Energy Materials and Solar Cells, vol. 37, pp. 1324, 1995.

(Received: August 20, 2011, Accepted: January 4, 2012) 